\title{
Comparison of the Transport Characteristics of Bioactive Substances in IUGR and Normal Placentas
}

\author{
ELISA KEATING, PEDRO GONÇALVES, FERNANDA COSTA, ISABEL CAMPOS, MARIA JOÃO PINHO, ISABEL AZEVEDO, \\ AND FÁTIMA MARTEL
}

Department of Biochemistry (U38/FCT) [E.K., P.G., I.A., F.M.], Institute of Pharmacology and Therapeutics [M.J.P.], University of Porto, 4200-319 Porto, Portugal; Department of Obstetrics and Gynaecology [F.C., I.C.], Hospital S. João, $4200-319$ Porto, Portugal

\begin{abstract}
Knowing that IUGR is associated with altered placental transport, we aimed to characterize the placental transport of folic acid (FA), thiamine (THIAM), serotonin (5-HT), and 1-methyl-4phenylpyridinium $\left(\mathrm{MPP}^{+}\right)$in IUGR. For this, we compared the transport characteristics of ${ }^{3} \mathrm{H}-\mathrm{FA},{ }^{3} \mathrm{H}$-THIAM, ${ }^{3} \mathrm{H}-5-\mathrm{HT}$, and ${ }^{3} \mathrm{H}-\mathrm{MPP}{ }^{+}$in primary cultured human cytotrophoblasts isolated from IUGR and normal placentas (GRTB and NTB cells, respectively) and quantified mRNA expression of several placental transporters, by real-time RT-PCR. Our results show that GRTB cells take up ${ }^{3} \mathrm{H}-\mathrm{FA}$ more efficiently (higher $k_{\text {in }}$ and $A_{\max }$ values) and have higher transport capacity (higher $V_{\max }$ values) for ${ }^{3} \mathrm{H}-\mathrm{FA},{ }^{3} \mathrm{H}-5-\mathrm{HT}$, and ${ }^{3} \mathrm{H}-\mathrm{MPP}^{+}$, when compared with NTB cells. In addition, GRTB cells take up ${ }^{3} \mathrm{H}$-THIAM with higher affinity and ${ }^{3} \mathrm{H}-\mathrm{MPP}^{+}$with lower affinity than NTB cells. Finally, IUGR placentas have a generalized increase in mRNA expression of FA, THIAM, 5-HT, and $\mathrm{MPP}^{+}$transporters, when compared with normal placentas, suggesting that the increase in transport capacity may be due to increased expression of placental transporters. These results point to an effect of "compensation for the weakness" of the IUGR placenta and pose the placenta as an active mediator of the communication between maternal and fetal environments. (Pediatr Res 66: 495-500, 2009)
\end{abstract}

I UGR is defined as the failure of a baby to fulfill his or her growth potential in utero (1) and occurs in $4-7 \%$ of births (2). This condition is associated with an increased risk of perinatal morbidity and mortality (3) and also of developing chronic adult diseases such as cardiovascular disease and glucose intolerance (4). The notion that IUGR is due to a reduced nutritional supply from the uteroplacental unit (3) poses placental insufficiency as a primary determinant of IUGR.

The aim of this work was to compare the transport function of IUGR and normal placentas. For this, we studied the transport characteristics of several bioactive substances in primary cultured human cytotrophoblasts isolated from IUGR placentas (GRTB cells) and from normal placentas (NTB cells). The bioactive substances studied were the group $\mathrm{B}$ vitamins, folic acid (FA), and thiamine (THIAM), and the two

Received March 20, 2009; accepted June 23, 2009.

Correspondence: Elisa Keating, Ph.D., Department of Biochemistry, Faculty of Medicine, University of Porto, 4200-319 Porto, Portugal; e-mail: keating@med.up.pt

Supported by the FCT and Programa Ciência, Tecnologia e Inovação do Quadro Comunitário de Apoio (POCTI/SAU-FCF/59382/2004). organic cations, serotonin (5-HT) and 1-methyl-4-phenylpyridinium $\left(\mathrm{MPP}^{+}\right)$. Furthermore, we compared the mRNA expression profile of several membrane carriers associated with the transport of these substances, in IUGR and normal placentas.

FA and THIAM are essential micronutrients for normal cellular functions, growth, and development and thus for pregnancy success. Indeed, FA deficiency during pregnancy is associated with low birth weight, increased risk of spontaneous abortion, and neural tube defects $(5,6)$, THIAM severe deficiency during pregnancy results in reduced fetal growth, congenital malformations, and fetal death (6), and supplementation with FA during the periconceptional period reduces the incidence of low birth weight newborns and neural tube defects (5). For these reasons, the study of FA and THIAM placental transport is of major importance.

5-HT acts as a vasoconstrictor and has been implicated in the regulation of blood flow in the uteroplacental circulation (7). Finally, the low molecular weight organic cation $\mathrm{MPP}^{+}$is considered a good model organic cation because, first, it is a very good substrate of many distinct transmembrane transporters of organic cations (see Ref. 8 for review), and second, because it is not subjected to metabolism (9). Because knowledge on placental transport of organic cations is very scarce, we decided to investigate also 5-HT and $\mathrm{MPP}^{+}$placental transport.

Placental alkaline phosphatase (PALP, EC 3.1.3.1) is a heat-stable ecto-isoenzyme, which is expressed at high levels in placental trophoblasts (10). Its expression starts around the seventh week of pregnancy and steadily increases with duration of gestation (10), suggesting that it may be physiologically important. Alkaline phosphatase (ALP) isoenzymes have been suggested to modulate several membrane transport systems at several tissue levels (11). Indeed, protein kinases and phosphatases are involved in the reversible control of cellular phosphorylation processes, which are critical in the regulation

Abbreviations: 5-HT, serotonin; FA, folic acid; GRTB, primary cultured growth-restricted human cytotrophoblasts; $\mathbf{M P P}^{+}$, 1-methyl-4-phenylpyridinium; NTB, primary cultured normal human cytotrophoblasts; PALP, placental alkaline phosphatase; THIAM, thiamine 
of protein activity. Therefore, in an attempt to unravel a putative role of PALP on the modulation of placental transport, we characterized an ecto-PALP activity in NTB cells and compared it with the ecto-PALP of GRTB cells.

Our results show that GRTB cells have a higher capacity to transport ${ }^{3} \mathrm{H}-\mathrm{FA},{ }^{3} \mathrm{H}-\mathrm{THIAM},{ }^{3} \mathrm{H}-5-\mathrm{HT}$, and ${ }^{3} \mathrm{H}-\mathrm{MPP}^{+}$, when compared to NTB cells, probably due to an up-regulation of transporter gene expression, suggesting that the IUGR placenta dynamically compensates for its own weakness.

\section{MATERIALS AND METHODS}

Collection of human placentas. Collection and processing of human placentas were approved by the Ethical Committee of Hospital S. João, Porto. Human placentas were obtained at the Department of Obstetrics and Gynaecology of Hospital S. João, Porto, from uncomplicated (control, $n=11$ ) and IUGR $(n=5)$ term pregnancies (37-40 wk), within half an hour after spontaneous delivery or elective caesarean section. Control placentas represented normal pregnancies with no associated maternal or fetal pathology and were collected at random. The IUGR placentas were not associated with other maternal or fetal pathology. The antepartum diagnosis of IUGR was based on ultrasonographic criteria. The diagnosis was confirmed if the birthweight was lower than the 10th percentile for gestational age, which was accurately calculated by fetal measurement on the ultrasonographic examination performed between the 11th and the 14th week of gestation. IUGR pregnancies were surveilled in our hospital and a decreased growth velocity was observed, with departure from the growth curve. All deliveries were programmed and occurred at term. Selected clinical data for normal or IUGR study groups are given in Table 1.

Primary culture of human cytotrophoblasts. Villous cytotrophoblasts (TB cells) corresponding to control or IUGR pregnancies (NTB and GRTB cells, respectively) were isolated using a modification of the technique described by Kliman (12), as previously described by Keating et al. (13). After $72 \mathrm{~h}$ in culture, TB cells aggregate to form syncytial clumps corresponding to syncytiotrophoblasts and were then used for transport experiments.

To evaluate the purity of the TB cell cultures, cells in chamber slides were fixed with $4 \%$ paraformaldehyde and immunolabeled with anti-vimentin and anti-cytokeratin antibodies. Ninety-five percent of the cells were cytokeratinpositive (thus corresponding to epithelial TB cells).

In vitro experiments. The transport experiments and the ecto-ALP assays were performed in buffer containing $125 \mathrm{mM} \mathrm{NaCl}, 4.8 \mathrm{mM} \mathrm{KCl}, 1.2 \mathrm{mM}$ $\mathrm{KH}_{2} \mathrm{PO}_{4}, 12.5 \mathrm{mM}$ HEPES-NaOH, $12.5 \mathrm{mM}$ MES, $1.2 \mathrm{mM} \mathrm{MgSO}_{4}, 1.2 \mathrm{mM}$ $\mathrm{CaCl}_{2}$, and $5.6 \mathrm{mM} \mathrm{D}(+)$ glucose, $\mathrm{pH} 7.5$ and 7.8 (unless otherwise stated), respectively.

When tested, drugs were present during both the preincubation and incubation periods. Controls for the drugs were run in the presence of the respective solvent, which was present in a final concentration of $1 \%$ in the buffer.

Transport studies were performed as previously described (14). Incubation periods were $6 \mathrm{~min}$ for ${ }^{3} \mathrm{H}-\mathrm{FA},{ }^{3} \mathrm{H}-5-\mathrm{HT}$, and ${ }^{3} \mathrm{H}-\mathrm{MPP}^{+}$, or $3 \mathrm{~min}$ for ${ }^{3} \mathrm{H}$-THIAM, unless otherwise stated. In time course experiments, ${ }^{3} \mathrm{H}-\mathrm{FA}$ was used at $10 \mathrm{nM}$.

Ecto-ALP assays were performed on cells grown for $96 \mathrm{~h}$. The ecto-ALP reaction was carried out, after a $30-\mathrm{min}$ preincubation period, with $2.5 \mathrm{mM}$ pNPP, except in the kinetic experiments (as indicated) and $1 \mathrm{mM} \mathrm{MgCl}$. After $60 \mathrm{~min}$ of incubation, the reaction was stopped by adding ice-cold $\mathrm{NaOH}(0.02 \mathrm{M})$. The amount of pNP released from pNPP, reflecting ectoALP activity, was measured at $405 \mathrm{~nm}$ (adapted from Ref. 15).

RNA extraction and real-time quantitative RT-PCR. Total RNA was extracted from NTB cells or placental villous tissue using the Tripure isolation reagent, according to manufacturer's instructions (Roche Diagnostics, Germany).

Before cDNA synthesis, total RNA was treated with DNase I (Invitrogen Corporation, CA) and $0.5 \mu \mathrm{g}$ of resulting DNA-free RNA was reverse transcribed using Superscript Reverse Transcriptase II and random hexamer primers (Invitrogen Corporation, CA) in $20 \mu \mathrm{L}$ of final reaction volume, according to manufacturer's instructions. Resulting cDNA was treated with RNase H (Invitrogen Corporation, CA) to degrade unreacted RNA. For the real-time quantitative PCR (qRT-PCR), $2 \mu \mathrm{L}$ of the $20 \mu \mathrm{L}$ reverse transcription reaction mixture was used. For the calibration curve, placental standard cDNA was diluted in five different concentrations.

Real-time PCR was carried out using a LightCycler (Roche, Nutley, NJ). Twenty microliter reactions were set up in microcapillary tubes using $0.5 \mu \mathrm{M}$ of each primer and $4 \mu \mathrm{L}$ of SYBR Green master mix (LightCycler FastStart DNA MasterPlus SYBR Green I, Roche). Cycling conditions were as follows: denaturation $\left(95^{\circ} \mathrm{C}\right.$ for $\left.5 \mathrm{~min}\right)$, amplification and quantification $\left[95^{\circ} \mathrm{C}\right.$ for $10 \mathrm{~s}$, annealing temperature (AT) for $10 \mathrm{~s}$, and $72^{\circ} \mathrm{C}$ for $10 \mathrm{~s}$, with a single fluorescence measurement at the end of the $72^{\circ} \mathrm{C}$ for $10 \mathrm{~s}$ segment] repeated 40 times, a melting curve program $\left[(\mathrm{AT}+10)^{\circ} \mathrm{C}\right.$ for $15 \mathrm{~s}$ and $95^{\circ} \mathrm{C}$ with a heating rate of $0.1^{\circ} \mathrm{C} / \mathrm{s}$ and continuous fluorescence measurement], and a cooling step to $40^{\circ} \mathrm{C}$. ATs, sequence of primers, primer position, and PCR product length are indicated in Table 2. Data were analyzed using LightCycler analysis software.

Immunodetection of ALP isozymes (dot-blot assay). The detection of ALP isozyme proteins in cellular lysates of NTB cells was performed in Hybond nitrocellulose membranes using anti-TNSALP and anti-PALP antibodies. Immunodetection was accomplished with enhanced chemiluminiscence using the ECL kit.

Protein determination. The protein content of cell monolayers was determined as described by Bradford (16), using BSA as standard.

Calculations and statistics. For the analysis of the time course of ${ }^{3} \mathrm{H}-\mathrm{FA}$ transport, the parameters of eq 1 were fitted to the experimental data by a nonlinear regression analysis, using a computer-assisted method (17).

$$
A(t)=k_{\text {in }} / k_{\text {out }}\left(1-e^{-k_{\text {out }}}\right)
$$

where $A(t)$ represents the accumulation of substrate at time $t, k_{\text {in }}$ and $k_{\text {out }}$ the rate constants for inward and outward transport, respectively, and $t$ the incubation time. $A_{\max }$ is defined as the accumulation at steady-state $(t \rightarrow \infty)$. $K_{\text {in }}$ is given in $\mathrm{pmol} \cdot \mathrm{mg}$ protein ${ }^{-1} \cdot \min ^{-1}$ and $k_{\text {out }}$ in $\min ^{-1}$. To obtain clearance values, $k_{\text {in }}$ was converted to $\mu \mathrm{L} \cdot \mathrm{mg}$ protein ${ }^{-1} \cdot \min ^{-1}$.

For the analysis of the saturation curve of either uptake of radioactive substrates or ecto-ALP activity, the parameters of the Michaelis-Menten equation were fitted to the experimental data by a nonlinear regression analysis, using a computer-assisted method (17).

Arithmetic means are given with SEM. Statistical significance of the difference between various groups was evaluated by one-way ANOVA test followed by the Bonferroni test. For comparison between two groups, $t$ test was used. Differences were considered to be significant when $p<0.05$.

Materials. ${ }^{3} \mathrm{H}-\mathrm{FA}\left(\left[3^{\prime}, 5^{\prime}, 7,9-{ }^{3} \mathrm{H}\right]\right.$ folic acid potassium salt; specific activity $21.0 \mathrm{Ci} \cdot \mathrm{mmol}^{-1}$ ) and ${ }^{3} \mathrm{H}-5$-HT $\left(5\right.$-hydroxy $\left[{ }^{3} \mathrm{H}\right]$ tryptamine trifluoroacetate; specific activity $104 \mathrm{Ci} \cdot \mathrm{mmol}^{-1}$ ) (Amersham Pharmacia Biotech, Buckinghamshire, UK); ${ }^{3} \mathrm{H}$-THIAM (thiamine $\mathrm{HCl},\left[{ }^{3} \mathrm{H}(\mathrm{G})\right]$, specific activity 10 $\left.\mathrm{Ci} \cdot \mathrm{mmol}^{-1}\right)$ and ${ }^{3} \mathrm{H}-\mathrm{MPP}^{+}\left(\mathrm{N}\right.$-[methyl- $\left.{ }^{3} \mathrm{H}\right]-4-$ phenylpyridinium acetate; specific activity $80 \mathrm{Ci} \cdot \mathrm{mmol}^{-1}$ ) (American Radiolabeled Chemicals, Inc., St. Louis, MO); folic acid, levamisole, L-phenylalanine, $\mathrm{MPP}^{+}$(1-methyl-4phenylpyridinium iodide), serotonin (5-hydroxytryptamine creatinine sulfate), DIDS (4,4'-diisothiocyanatostilbene-2,2'-disulfonic acid disodium salt), 5-MTHF (5-methyltetrahydrofolic acid disodium salt), MTX (amethopterin), pargyline hydrochloride, ascorbic acid, FBS, DMEM, HEPES ( $N-2-$ hydroxyethylpiperazine- $N^{\prime}$-2-ethanesulfonic acid), MES (2-[N-morpholino] ethanesulfonic acid hydrate), DNAse I, Percoll, antibiotic/antimycotic solution (100 units $\cdot \mathrm{mL}^{-1}$ penicillin; $100 \mu \mathrm{g} \cdot \mathrm{mL}^{-1}$ streptomycin and 0.25 $\mu \mathrm{g} \mathrm{mL}{ }^{-1}$ amphotericin B), pNPP ( $p$-nitrophenylphosphate), pNP ( $p$ nitrophenol), MTT (3-(4,5-dimethyl-2-thiazolyl)-2,5-diphenyl-2H-tetrazolium bromide) (Sigma Chemical Co., St. Louis, MO). DMSO, Triton X-100, Tris (tris-(hydroxymethyl)-aminomethane hydrochloride), trypsin (10× solution) (GIBCO, Invitrogen Corporation, Carlsbad, CA); ECL kit (Amersham Biosciences, USA); Anti-TNSALP and anti-PALP antibodies (Santacruz Biotechnology, Santacruz, CA); Hybond nitrocellulose membranes (Amersham Biosciences, USA); and Tripure isolation reagent (Roche Diagnostics, Germany).

Table 1. Selected clinical data

\begin{tabular}{lrcccc}
\hline & $n$ & Maternal age $(\mathrm{y})$ & Gestational age $(w k)$ & Placental weight $(\mathrm{g})$ & Birth weight $(\mathrm{g})$ \\
\hline Controls & 11 & $34.0 \pm 1.9$ & $38.8 \pm 0.7$ & $563.2 \pm 31.5$ & $3161.4 \pm 134.8$ \\
IUGR & 5 & $31.6 \pm 1.6$ & $37.1 \pm 0.5$ & $401.4^{*} \pm 34.2$ & $2114.6^{*} \pm 98.5$ \\
\hline
\end{tabular}

\footnotetext{
* Significantly different from controls $(p<0.05)$.
} 
Table 2. Primer position, sequence and annealing temperatures (AT), and PCR product length used for real-time qRT-PCR

\begin{tabular}{|c|c|c|c|c|c|}
\hline Gene name & Primer position & & Primer sequence $\left(5^{\prime}\right.$ to $\left.3^{\prime}\right)$ & $\mathrm{AT}\left({ }^{\circ} \mathrm{C}\right)$ & PCR product length $(\mathrm{bp})$ \\
\hline \multirow[t]{2}{*}{$\mathrm{RFC1}$} & $1139 / 1140$ & $\mathrm{~F}$ & GCC CAT CGC CAC CTT TCA GAT & 65 & 127 \\
\hline & $1247 / 1248$ & $\mathrm{R}$ & CCG CAC GTC CGA GAC AAT GA & & \\
\hline \multirow[t]{2}{*}{$\mathrm{FR} \alpha$} & $152 / 153$ & $\mathrm{~F}$ & CAA GTT GCA TGA GCA GTG TCG & 59 & 116 \\
\hline & $248 / 249$ & $\mathrm{R}$ & CAC AGT GGT TCC AGT TGA ATC & & \\
\hline \multirow[t]{2}{*}{ PCFT } & $673 / 674$ & $\mathrm{~F}$ & ATG CAG CTT TCT GCT TTG GT & 59 & 100 \\
\hline & $754 / 755$ & $\mathrm{R}$ & GGA GCC ACA TAG AGC TGG AC & & \\
\hline \multirow[t]{2}{*}{ ThTr1 } & $410 / 411$ & $\mathrm{~F}$ & CGT TTC AAC CTT ACT GGG TGC & 62 & 115 \\
\hline & $505 / 506$ & $\mathrm{R}$ & TGC AGC AGC AAT CAG GAG AGA & & \\
\hline \multirow[t]{2}{*}{ SERT } & $961 / 962$ & $\mathrm{~F}$ & TGG AGA CAG GGG TGT GGA TA & 60 & 123 \\
\hline & $1064 / 1065$ & $\mathrm{R}$ & GGG CAT CTT GGT AGC AGT TGT & & \\
\hline \multirow[t]{2}{*}{ OCT3* } & $421 / 422$ & $\mathrm{~F}$ & TCA GCG AGT TTG ACC TTG TCT & 58 & 131 \\
\hline & $532 / 533$ & $\mathrm{R}$ & AAT GAC GAT CCT GCC ATA CCT & & \\
\hline \multirow[t]{2}{*}{ PALP } & $516 / 517$ & $\mathrm{~F}$ & GCC AAG AAA GCA GGG AAG TCA & 63 & 88 \\
\hline & $587 / 588$ & $\mathrm{R}$ & TCA CCG TGT GGG CGT AGG & & \\
\hline
\end{tabular}

* Primer sequence obtained from Ref. 19.

RFC1, human reduced folate carrier; FR $\alpha$, human folate receptor alpha; PCFT, human proton-coupled folate transporter; ThTr1, human thiamine transporter type 1; SERT, human 5-HT transporter; OCT3, human organic cation transporter type 3; PALP, human placental alkaline phosphatase; F, forward; R, reverse.
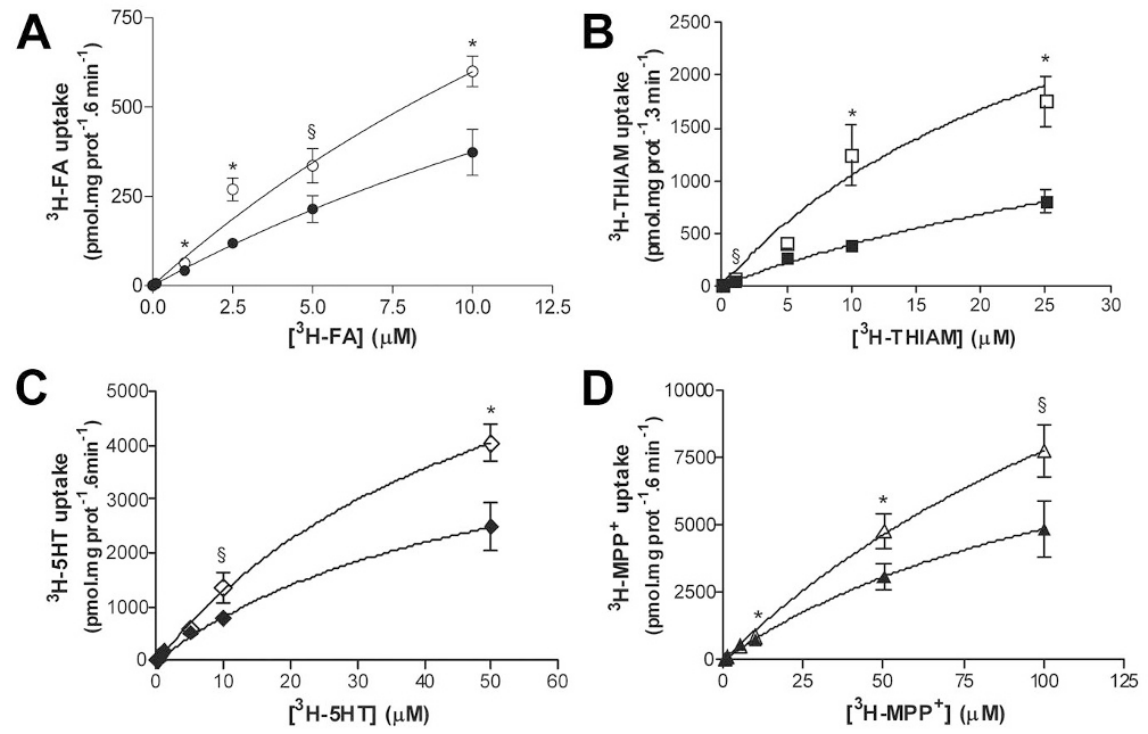

Figure 1. Kinetics of the uptake of ${ }^{3} \mathrm{H}-\mathrm{FA}(n=$ $8-10)(A),{ }^{3} \mathrm{H}$-THIAM $(n=7-12)(B),{ }^{3} \mathrm{H}-5$-HT $(n=8-9)(C)$, and ${ }^{3} \mathrm{H}-\mathrm{MPP}^{+}(n=9-11)(D)$ by NTB (solid bullets) and GRTB (open bullets) cells. Cells were incubated at $37^{\circ} \mathrm{C}$ and $\mathrm{pH} 7.5$, for $6 \mathrm{~min}$, in the presence of increasing concentrations of ${ }^{3} \mathrm{H}-\mathrm{FA} \quad(0.01-10 \mu \mathrm{M}),{ }^{3} \mathrm{H}-5-\mathrm{HT}$ $(0.05-50 \mu \mathrm{M}),{ }^{3} \mathrm{H}-\mathrm{MPP}^{+}(0.2-100 \mu \mathrm{M})$, or for 3 min with ${ }^{3} \mathrm{H}$-THIAM $(0.1-25 \mu \mathrm{M})$. Shown are arithmetic means \pm SEM. $*, \S$ Significantly different from NTB cells $(* p<0.05 ; \S p<0.075)$.

\section{RESULTS}

Kinetics of ${ }^{3} \mathrm{H}-\mathrm{FA},{ }^{3} \mathrm{H}-\mathrm{THIAM},{ }^{3} \mathrm{H}-5-\mathrm{HT}$, and ${ }^{3} \mathrm{H}-\mathrm{MPP}{ }^{+}$ uptake by TB cells. In this set of experiments, we determined the initial rates of ${ }^{3} \mathrm{H}-\mathrm{FA},{ }^{3} \mathrm{H}-\mathrm{THIAM},{ }^{3} \mathrm{H}-5$-HT, or ${ }^{3} \mathrm{H}-\mathrm{MPP}^{+}$ uptake at increasing substrate concentrations, both in NTB and GRTB cells (Fig. 1).

Kinetic parameters of each saturation curve are shown in Table 3. Curiously, the $V_{\max }$ values for all the substrates tested were 1.5-2 times higher in GRTB cells than in NTB (these differences were statistically significant for all substances except for THIAM). With respect to affinity, the $K_{\mathrm{m}}$ of ${ }^{3} \mathrm{H}$-THIAM uptake was 2 times lower, and that of ${ }^{3} \mathrm{H}-\mathrm{MPP}^{+}$ uptake was 1.5 times higher in GRTB when compared with NTB cells. On the other hand, no differences were found between $K_{\mathrm{m}}$ values for ${ }^{3} \mathrm{H}-\mathrm{FA}$ and ${ }^{3} \mathrm{H}-5$-HT uptake.

Time course of ${ }^{3} \mathrm{H}-\mathrm{FA}$ uptake by TB cells. We also determined the time course of accumulation of ${ }^{3} \mathrm{H}-\mathrm{FA}$ in NTB and
Table 3. Kinetic parameters of the uptake of ${ }^{3} H-F A,{ }^{3} H$-THIAM,

\begin{tabular}{|c|c|c|c|}
\hline & $V_{\max }\left(\mathrm{pmol} \cdot \mathrm{mg} \cdot \operatorname{protein} \cdot \min ^{-1}\right)$ & $K_{\mathrm{m}}(\mathrm{mM})$ & $n$ \\
\hline \multicolumn{4}{|l|}{${ }^{3} \mathrm{H}-\mathrm{FA}$} \\
\hline NTB & $1,535 \pm 47$ & $31.0 \pm 1.2$ & 10 \\
\hline GRTB & $2,292^{*} \pm 293$ & $28.3 \pm 4.7$ & 8 \\
\hline \multicolumn{4}{|c|}{${ }^{3} \mathrm{H}$-THIAM } \\
\hline NTB & $2,692 \pm 257$ & $59.6 \pm 30.4$ & 12 \\
\hline GRTB & $4,213 \pm 838$ & $30.4 * \pm 8.6$ & 7 \\
\hline \multicolumn{4}{|l|}{${ }^{3} \mathrm{H}-5 \mathrm{HT}$} \\
\hline NTB & $5,116 \pm 128$ & $53.4 \pm 2.4$ & 9 \\
\hline GRTB & $8,655^{*} \pm 208$ & $57.0 \pm 2.4$ & 8 \\
\hline \multicolumn{4}{|l|}{${ }^{3} \mathrm{H}-\mathrm{MPP}^{+}$} \\
\hline NTB & $11,612 \pm 275$ & $138.4 \pm 5.2$ & 11 \\
\hline GRTB & $23,595^{*} \pm 977$ & $203.2 * \pm 11.8$ & 9 \\
\hline
\end{tabular}

* Significantly different from NTB cells taken as controls $(p<0.05)$.

Cells were incubated at $37^{\circ} \mathrm{C}$ and $\mathrm{pH} 7.5$ for $6 \mathrm{~min}$ with increasing concentrations of ${ }^{3} \mathrm{H}-\mathrm{FA}(0.01-10 \mu \mathrm{M}),{ }^{3} \mathrm{H}-5-\mathrm{HT}(0.05-50 \mu \mathrm{M}),{ }^{3} \mathrm{H}-\mathrm{MPP}^{+}$ $(0.2-100 \mu \mathrm{M})$, or for $3 \mathrm{~min}$ with ${ }^{3} \mathrm{H}$-THIAM $(0.1-25 \mu \mathrm{M})$. Shown are arithmetic mean \pm SEM. 


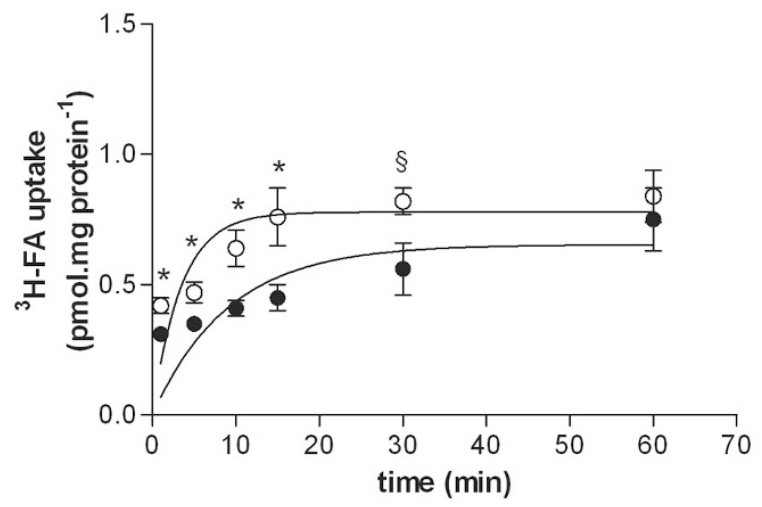

Figure 2. Time course of the uptake of ${ }^{3} \mathrm{H}-\mathrm{FA}(10 \mathrm{nM}, n=5-9)$ by NTB (solid bullets) and GRTB (open bullets) cells. Cells were incubated at $37^{\circ} \mathrm{C}$ and $\mathrm{pH} 7.5$ for various periods of time. Shown are arithmetic means \pm SEM. ${ }^{*}{ }^{8}$ Significantly different from NTB cells $(* p<0.05 ; \S p<0.075)$.

GRTB cells. For this, cells were incubated at $\mathrm{pH} 7.5$ with 10 $\mathrm{nM}{ }^{3} \mathrm{H}-\mathrm{FA}$ for various periods of time.

Analysis of the time course (Fig. 2) allowed the determination of values of the steady-state accumulation $\left(A_{\max }\right.$, $0.65 \pm 0.03, n=9$, and $0.78 \pm 0.03, n=5$, for NTB and GRTB cells, respectively), the rate constant of inward transport $\left(k_{\mathrm{in}}, 7.16 \pm 0.79, n=9\right.$, and $22.21 \pm 3.80, n=5$, for NTB and GRTB cells, respectively), and the rate constant of outward transport $\left(k_{\text {out }}, 0.11 \pm 0.02, n=9\right.$, and $0.28 \pm 0.05$, $n=5$, for NTB and GRTB cells, respectively). Both the $k_{\text {in }}$ and the $k_{\text {out }}$ were significantly higher in GRTB than in NTB cells. Specifically, an amount of NTB cells corresponding to 1 $\mathrm{mg}$ of cell protein cleared $7.16 \mu \mathrm{L}$ incubation medium of ${ }^{3} \mathrm{H}-\mathrm{FA}$ per minute, and simultaneously, $11 \%$ of intracellular ${ }^{3} \mathrm{H}$-FA left the cells per minute. The same amount of GRTB cells cleared 3 times more incubation medium of ${ }^{3} \mathrm{H}-\mathrm{FA}$ per minute and extruded as much as $28 \%$ of intracellular ${ }^{3} \mathrm{H}$-FA from the cells per min. As a result, the $A_{\max }$ for ${ }^{3} \mathrm{H}-\mathrm{FA}$ was significantly higher in GRTB than in NTB cells.

Ecto-ALP activity in NTB cells: dependence on culture time and on extracellular pH. Ecto-ALP activity was quantified in NTB cells cultivated for various periods of time. Ecto-ALP activity increased for up to $2 \mathrm{~d}$ of culture and thereafter remained unchanged for up to $4 \mathrm{~d}$ of culture (Fig. $3 A$ ). L-phenylalanine (PHE; $2 \mathrm{mM}$ ), an inhibitor of the placental isoenzyme of ALP (PALP), inhibited ecto-ALP activity from culture d 2-4. Unexpectedly, levamisole (LEV; $1 \mathrm{mM}$ ), an inhibitor of the tissue nonspecific isoenzyme of ALP (TNSALP), also reduced ecto-ALP activity from culture day $1-4$. Nevertheless, the ratio of inhibition in the presence of PHE or LEV (PHE/LEV) remained unchanged with culture time (Fig. 3A), indicating that the type of ecto-ALP present does not seem to change. On the basis of this information, for practical reasons, ecto-ALP assays were performed in cells cultivated for $4 \mathrm{~d}$.

Not surprisingly, ecto-ALP activity was found to be $\mathrm{pH}-$ dependent (Fig. $3 B$ ), reaching its maximum at $\mathrm{pH}$ 9.0. In addition, PHE $2 \mathrm{mM}$ inhibited ALP activity from $\mathrm{pH} 7.8$ to 9.0. Cell viability was not compromised when cells were exposed to increasing $\mathrm{pH}$ values (up to 9.0; data not shown). Therefore, in subsequent experiments, ecto-ALP activity was
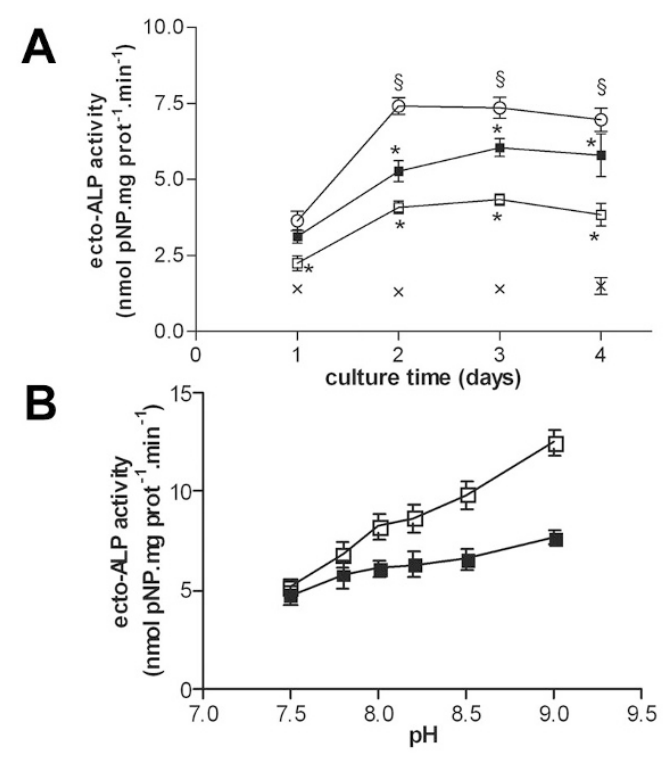

Figure 3. Dependence of ecto-ALP activity in NTB cells in relation to: culture time $(A)$ and $\mathrm{pH}(B)$, and effect of ecto-ALP inhibitors. (A) Cells were cultivated for various periods of time and then incubated for $60 \mathrm{~min}$ with 2.5 $\mathrm{mM}$ pNPP in the presence of L-phenylalanine (PHE $2 \mathrm{mM} ; n=4 ; \square$ ), levamisole (LEV $1 \mathrm{mM} ; n=5 ; \square$ ), or the respective solvent $(\mathrm{C} ; n=7 ; \bigcirc$ ), at $\mathrm{pH} 7.8 ; \times$ : relative contribution of ecto-ALP activities under the influence of PHE or LEV (PHE/LEV); (B) cells were incubated for 60 min with $2.5 \mathrm{mM}$ pNPP at increasing pH values (7.5-9.0) in the presence of L-phenylalanine (PHE $2 \mathrm{mM} ; n=6$; $\square$ ) or the respective solvent $(C ; n=6$; $\square$ ). Shown are arithmetic means \pm SEM. *, $\S$ Significantly different from control or day 1 , respectively, $(p<0.05)$.

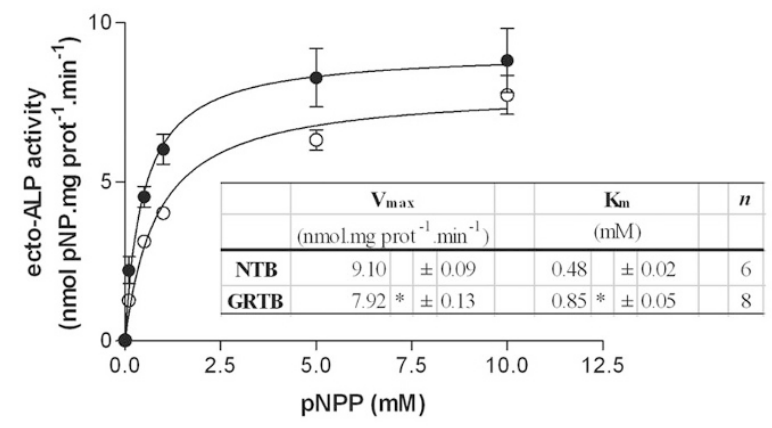

Figure 4. Kinetics of ecto-ALP activity. NTB $(\bullet)$ or GRTB $(\bigcirc)$ cells were

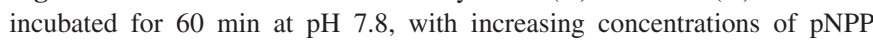
$(0.1-10 \mathrm{mM})(n=6)$. Shown are arithmetic means \pm SEM. *Significantly different from control $(p<0.05)$.

determined at $\mathrm{pH} 7.8$, which is a $\mathrm{pH}$ not very different from the physiologic $\mathrm{pH}$ and at which the enzyme activity can be easily measured.

In these series of experiments, we studied the variation of ecto-ALP activity with increasing substrate concentrations (pNPP, 0.1-10 mM), both in NTB and GRTB cells (Fig. 4). Ecto-ALP activity was found to be saturable in both cell types. Interestingly, $V_{\max }$ value of ecto-ALP activity in NTB cells was higher, and $K_{\mathrm{m}}$ value lower, than in GRTB cells.

ALP isoenzyme detection. The finding that ecto-ALP activity was inhibited by LEV led us to investigate the presence of TNSALP in NTB cells. Therefore, we performed RT-PCR 


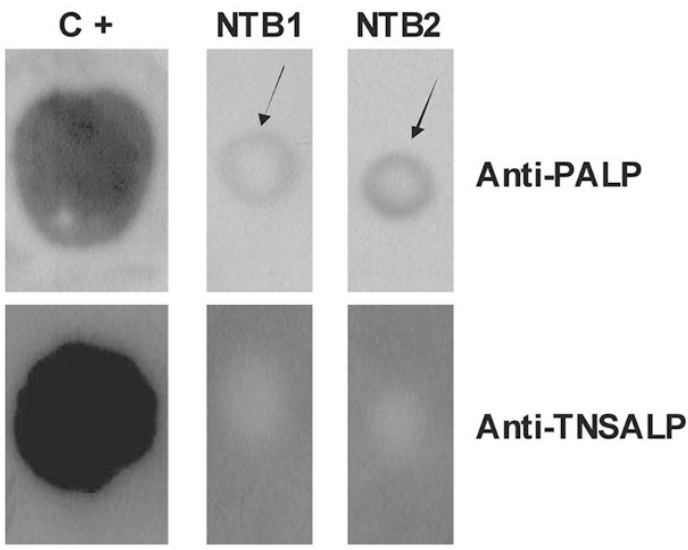

Figure 5. Detection of tissue nonspecific (TNSALP) and placental (PALP) alkaline phosphatase protein, by dot-blot assay, in NTB cells. Isoenzyme proteins of NTB cells (NTB 1 and 2) or leukocyte lysates (control; $\mathrm{C}+$ ) were detected using anti-PALP and anti-TNSALP antibodies and enhanced chemiluminescence.

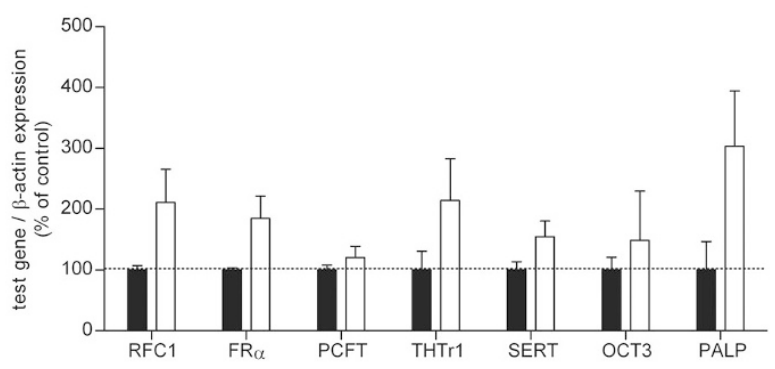

Figure 6. mRNA levels of reduced folate carrier (RFC1), folate receptor alpha $(\mathrm{FR} \alpha)$, proton-coupled folate transporter (PCFT), thiamine transporter type 1 (ThTr1), serotonin transporter (SERT), organic cation transporter type 3 (OCT3), and placental alkaline phosphatase (PALP) in normal (NP, control taken as $100 \%, n=4$; $\square$ ) and growth-restricted (GRP, $n=5$; $\square$ ) placental villous tissue determined by qRT-PCR. Shown are arithmetic means \pm SEM corresponding to the expression of each test gene relative to $\beta$-actin.

with total RNA from NTB cells and dot-blot assay with NTB cell lysates.

NTB cells expressed PALP, but not TNSALP mRNA (data not shown). This result was confirmed by immunodetection of both isoenzymes: NTB cells were positive for PALP but negative for TNSALP (Fig. 5).

Quantification of mRNA expression in normal and growth-restricted placentas. To understand whether the observed increase in transport activity in GRTB cells was due to an increase in the transcription of membrane transporters in IUGR placentas, we quantified the mRNA levels of several transporters in normal (control, NP) and growth-restricted (GRP) placental villous tissue, by qRT-PCR. The genes encoding the following transporters were quantified: the reduced folate carrier (RFC1), the folate receptor alpha ( $\mathrm{FR} \alpha)$, and the proton-coupled folate transporter (PCFT), which are known to be involved in FA placental transport $(14,18,19)$; the THIAM transporter type 1 (ThTr1) (20), which is thought to be involved in THIAM placental transport; the serotonin transporter (SERT), which has been suggested to participate in THIAM (21) and $\mathrm{MPP}^{+}$(8) transport in BeWo and JAR cells, respectively, and is known to be involved in the placental uptake of 5-HT (22); and the organic cation transporter type 3 (OCT3), which is known to be involved in $\mathrm{MPP}^{+}$transport in human placental basal membrane vesicles (23). Because we also investigated a putative involvement of PALP in placental transport, we also quantified the expression levels of PALP in both NP and GRP.

As shown in Fig. 6, a generalized (although not statistically significant) increase in the mRNA levels of all the studied genes in GR placentas relative to normal controls was observed.

\section{DISCUSSION}

The aim of this work was to compare the transport characteristics of several bioactive substances (the vitamins FA and THIAM, and the organic cations 5-HT and $\mathrm{MPP}^{+}$) in primary cultured human cytotrophoblasts isolated from IUGR (GRTB cells) and control placentas (NTB cells).

Human primary cultured cytotrophoblasts (TB cells) are recognized as a suitable cell model to study human placental transport and function (24) because villous cytotrophoblast cells in culture spontaneously differentiate into a functional and polarized syncytiotrophoblast-like structure that resembles the in vivo syncytiotrophoblast $(25,26)$.

From the kinetic analysis, we conclude that GRTB cells have a higher transport capacity (higher $V_{\max }$ ) both for the vitamins and for the organic cations tested, when compared with NTB cells. Moreover, we observed that GRTB cells take up ${ }^{3} \mathrm{H}$-THIAM with greater affinity (lower $K_{\mathrm{m}}$ ) than NTB cells. The time course analysis of ${ }^{3} \mathrm{H}-\mathrm{FA}$ uptake reinforces the kinetic results, demonstrating that GRTB cells are indeed more efficient in taking up and accumulating this vitamin, when compared with their normal counterparts.

To our knowledge, this is the first report showing changes in transport of FA, THIAM, 5-HT, and MPP ${ }^{+}$in IUGR. Given the physiologic importance of these particular substances in pregnancy (FA and THIAM as obligatory vitamins for fetal development, 5-HT as a placental vasoconstrictor, and $\mathrm{MPP}^{+}$ as a model for organic cation), the results of this study are with no doubt important.

IUGR has already been shown to be associated with altered placental transport of some substances (3). In that context, it has been hypothesized that down-regulation of placental transporters in IUGR may correspond to a primary event or cause in the onset of this pathology and that the up-regulation may be secondary or compensatory for growth restriction (3). Our results are in perfect agreement with this hypothesis. Indeed, we here detect a higher transport activity in GRTB cells for all the bioactive substances tested, when compared with NTB cells (for ${ }^{3} \mathrm{H}$-THIAM, this increase was evident although statistically not significant), and we suggest that this compensation in activity may result from an up-regulation in transporter gene expression.

We also characterized an ecto-PALP activity in NTB cells and compared it with the ecto-PALP assayed in GRTB cells. We demonstrated for the first time an ecto-ALP activity in this cell model. This activity was shown to be inhibited by PHE, but unexpectedly, it was more potently inhibited by LEV, an inhibitor of TNS-ALP. However, NTB cells do not express TNS-ALP. Therefore, it seems that LEV inhibits PALP. More- 
over, we verified that the enzyme activity is saturable and has a $K_{\mathrm{m}}$ value identical to that found for the purified form of PALP (27). This observation, together with the results from the characterization described above, reinforces the idea that the ectoALP activity detected in this study is indeed due to PALP.

Quantification of ecto-ALP activity in GRTB cells showed that it is reduced and has a lower affinity for the substrate when compared with NTB cells. This finding is in strong agreement with the observation that serum levels of PALP are lowered in pregnancies complicated by IUGR (28) and may result from a reduced villous surface area seen in growthrestricted placentas (29). Reinforcing this association is the demonstration by Calhau et al. (11) that there is a positive correlation between ALP activity and the extent of exchange surfaces.

We observed, by qRT-PCR analysis, that PALP mRNA levels are increased in GRP when compared with NP. Although this finding may seem unexpected, it is in agreement with the increased differentiation observed by Newhouse et al. (30) in IUGR trophoblast cultures. The disparity between ecto-PALP activity and mRNA levels suggests that there may be an increased transcription of PALP in IUGR, but a defective translation or inefficient recycling of the enzyme to the cell surface. Indeed, PALP is an ecto-enzyme, which is subjected to recycling between intracellular compartments and the cell surface (15).

In conclusion, our results show that GRTB cells have higher capacity to transport ${ }^{3} \mathrm{H}-\mathrm{FA},{ }^{3} \mathrm{H}-\mathrm{THIAM},{ }^{3} \mathrm{H}-5-\mathrm{HT}$, and ${ }^{3} \mathrm{H}-\mathrm{MPP}^{+}$, probably due to an up-regulation of transporter gene expression. These observations point to an effect of "compensation for the weakness" of the growth-restricted placenta and pose the placenta as an active mediator of the communication between maternal and fetal environments.

Our results also show that GRTB cells have lower ectoPALP activity when compared with NTB cells; further work aimed at studying a putative involvement of ecto-PALP on the modulation of placental transport, as demonstrated for other ALP isoenzymes, is therefore warranted (11).

Acknowledgments. We thank Professor Seth Guller (Yale University, New Haven, CT, USA) for technical support in establishing primary cultures; Dr. Joana Marques (University of Porto, Portugal) for $\beta$-actin primers donation; Dr. Otília Brandão (University of Porto, Portugal) for technical help with GR placentas; and Mrs. Luisa Vasques (University of Porto, Portugal) for laboratory support.

\section{REFERENCES}

1. Monk D, Moore GE 2004 Intrauterine growth restriction-genetic causes and consequences. Semin Fetal Neonatal Med 9:371-378

2. McCarthy C, Cotter FE, McElwaine S, Twomey A, Mooney EE, Ryan F, Vaughan J 2007 Altered gene expression patterns in intrauterine growth restriction: potential role of hypoxia. Am J Obstet Gynecol 196:70.e1-70.e6
3. Cetin I, Foidart JM, Miozzo M, Raun T, Jansson T, Tsatsaris V, Reik W, Cross J, Hauguel-de-Mouzon S, Illsley N, Kingdom J, Huppertz B 2004 Fetal growth restriction: a workshop report. Placenta 25:753-757

4. Barker DJ 1998 In utero programming of chronic disease. Clin Sci (Lond) 95:115128

5. Picciano MF 2003 Pregnancy and lactation: physiological adjustments, nutritional requirements and the role of dietary supplements. J Nutr 133:1997S-2002S

6. Worthington-Roberts B 1999 Nutrition. In: Cohen W, Cherry S, Merkatz I (eds) Cherry and Merkatz's Complications of Pregnancy. Lippincott Williams \& Wilkins, London; pp 17-49

7. Bolte AC, van Geijn HP, Dekker GA 2001 Pathophysiology of preeclampsia and the role of serotonin. Eur J Obstet Gynecol Reprod Biol 95:12-21

8. Martel F, Keating E 2003 Uptake of 1-methyl-4-phenylpyridinium (MPP+) by the JAR human placental choriocarcinoma cell line: comparison with 5-hydroxytryptamine. Placenta 24:361-369

9. Sayre LM 1989 Biochemical mechanism of action of the dopaminergic neurotoxin 1-methyl-4-phenyl-1,2,3,6-tetrahydropyridine (MPTP). Toxicol Lett 48:121-149

10. Leitner K, Szlauer R, Ellinger I, Ellinger A, Zimmer KP, Fuchs R 2001 Placental alkaline phosphatase expression at the apical and basal plasma membrane in term villous trophoblasts. J Histochem Cytochem 49:1155-1164

11. Calhau C, Hipolito-Reis C, Azevedo I 1999 Alkaline phosphatase and exchange surfaces. Clin Biochem 32:153-154

12. Kliman HJ, Nestler JE, Sermasi E, Sanger JM, Strauss JF 3rd 1986 Purification, characterization, and in vitro differentiation of cytotrophoblasts from human term placentae. Endocrinology 118:1567-1582

13. Keating E, Goncalves P, Lemos C, Costa F, Campos I, Smith SB, Bridges CC, Martel F 2007 Progesterone inhibits folic acid transport in human trophoblasts. J Membr Biol 216:143-152

14. Keating E, Lemos C, Goncalves P, Martel F 2008 Acute and chronic effects of some dietary bioactive compounds on folic acid uptake and on the expression of folic acid transporters by the human trophoblast cell line BeWo. J Nutr Biochem 19:91-100

15. Anagnostou F, Plas C, Forest N 1996 Ecto-alkaline phosphatase considered as levamisole-sensitive phosphohydrolase at physiological $\mathrm{pH}$ range during mineralization in cultured fetal calvaria cells. J Cell Biochem 60:484-494

16. Bradford MM 1976 A rapid and sensitive method for the quantitation of microgram quantities of protein utilizing the principle of protein-dye binding. Anal Biochem 72:248-254

17. Muzyka A, Tarkany O, Yelizanof V, Sergienko U, Boichuk A 2005 Non-linear regression (curve fit), in GraphPad Prism (version 4.03) for Windows. GraphPad Software, San Diego, CA

18. Ganapathy V, Smith SB, Prasad PD 2004 SLC19: the folate/thiamine transporter family. Pflugers Arch 447:641-646

19. Qiu A, Jansen M, Sakaris A, Min SH, Chattopadhyay S, Tsai E, Sandoval C, Zhao R, Akabas MH, Goldman ID 2006 Identification of an intestinal folate transporter and the molecular basis for hereditary folate malabsorption. Cell 127:917-928

20. Dutta B, Huang W, Molero M, Kekuda R, Leibach FH, Devoe LD, Ganapathy V, Prasad PD 1999 Cloning of the human thiamine transporter, a member of the folate transporter family. J Biol Chem 274:31925-31929

21. Keating E, Lemos C, Azevedo I, Martel F 2006 Characteristics of thiamine uptake by the BeWo human trophoblast cell line. J Biochem Mol Biol 39:383-393

22. Nguyen TT, Tseng YT, McGonnigal B, Stabila JP, Worrell LA, Saha S, Padbury JF 1999 Placental biogenic amine transporters: in vivo function, regulation and pathobiological significance. Placenta 20:3-11

23. Sata R, Ohtani H, Tsujimoto M, Murakami H, Koyabu N, Nakamura T, Uchiumi T, Kuwano M, Nagata H, Tsukimori K, Nakano H, Sawada Y 2005 Functional analysis of organic cation transporter 3 expressed in human placenta. J Pharmacol Exp Ther 315:888-895

24. Sastry BV 1999 Techniques to study human placental transport. Adv Drug Deliv Rev 38:17-39

25. Bloxam DL, Bax CM, Bax BE 1997 Culture of syncytiotrophoblast for the study of human placental transfer. I. Isolation and purification of cytotrophoblast. Placenta 18:93-98

26. Moreau R, Simoneau L, Lafond J 2001 Characteristics of calcium uptake by BeWo cells, a human trophoblast cell line. Placenta 22:768-775

27. Komoda T, Hokari S, Sonoda M, Sakagishi Y, Tamura T 1982 L-Phenylalanine inhibition of human alkaline phosphatases with $p$-nitrophenyl phosphate as substrate. Clin Chem 28:2426-2428

28. Holmgren PA, Stigbrand T, Damber MG, von Schoultz B 1979 Serum levels of placental alkaline phosphatase in high-risk pregnancies. Obstet Gynecol 54:631-634

29. Mayhew TM, Manwani R, Ohadike C, Wijesekara J, Baker PN 2007 The placenta in pre-eclampsia and intrauterine growth restriction: studies on exchange surface areas, diffusion distances and villous membrane diffusive conductances. Placenta 28:233-238

30. Newhouse SM, Davidge ST, Winkler-Lowen B, Demianczuk N, Guilbert LJ 2007 In vitro differentiation of villous trophoblasts from pregnancies complicated by intrauterine growth restriction with and without pre-eclampsia. Placenta 28:999-1003 